\title{
The Effect of Group Investigation Learning Model with Brainstroming Technique on Students Learning Outcomes
}

\author{
Kadek Ayu Astiti \\ Physics Education Study Program, Mathematics and natural science department \\ Faculty of Teacher Training and Education, Nusa Cendana University \\ Kupang, Indonesia \\ email: kadekayuastiti88@yahoo.com
}

\begin{abstract}
This study aims to determine the effect of group investigation (GI) learning model with brainstorming technique on student physics learning outcomes (PLO) compared to jigsaw learning model with brainstroming technique. The learning outcome in this research are the results of learning in the cognitive domain. The method used in this research is experiment with Randomised Postest Only Control Group Design. Population in this research is all students of class XI IPA SMA Negeri 9 Kupang year lesson 2015/2016. The selected sample are 40 students of class XI IPA 1 as the experimental class and 38 students of class XI IPA 2 as the control class using simple random sampling technique. The instrument used is 13 items description test. The first hypothesis was tested by using two tailed t-test. From that, it is obtained that $\mathrm{H}_{0}$ rejected which means there are differences of students physics learning outcome. The second hypothesis was tested using one tailed t-test. It is obtained that $\mathrm{H}_{0}$ rejected which means the students PLO in experiment class were higher than control class. Based on the results of this study, researchers recommend the use of GI learning models with brainstorming techniques to improve PLO, especially in the cognitive domain.
\end{abstract}

Keywords: Group Investigation Learning Model, Brainstroming technique, Students Learning Outcomes 


\section{INTRODUCTION}

Progress of a nation is determined by the quality of the education system. Aware of this, every nation is competing with various efforts to improve the quality of education in their respective countries. The strategic issues of education in Indonesia continue to roll and are not solved, although various solutions continue to be done. As for the background of the occurrence of these strategic issues is due to discrepancy, diversity, and inequity [7]. These strategic educational issues are reinforced by various research results, like: 1) Research by Suyanto and Hisham in 2000 stated that in the micro scale the learning process in almost all levels of education focuses only on the left brain, while the right brain is rarely developed. This condition causes national education not to produce people who are independent, creative and have self awareness [7], 2) In Education Development Index (EDI) 2011 Indonesia is ranked 69th of 127 countries, 3) According to the Education For All Global Monitoring Report 2012 released by the United Nations Educational, Scientific and Cultural Organization (UNESCO), Indonesia's education is ranked 64th for education worldwide from 120 countries, 4) Based on data from the 2012 Program for International Student Assessment (PISA) 2012, Indonesia ranks 64th out of 65 countries. This shows the quality of education Indonesia is in the second worst position in the world after Peru [16].

Based on these strategic issues, efforts have been made to improve and improve the quality of education in Indonesia. Efforts to improve the quality of education is marked by the renewal of the education system from time to time, one of which is through curriculum renewal. The learning process that develops in the classroom is generally determined by the role of teachers and students as individuals directly involved in the process. Students' ability depends on the way the teacher teaches. According to Law no. 20 in 2003, learning is the process of interaction of learners with educators and learning resources in a learning environment.

In science lessons, particularly physics, active learning methods are very important to thoroughly understand. Physics is one of the science lessons, and is a discipline based on qualitative and quantitative measurements for understanding natural phenomena around us. Students have difficulty learning physics because physics consists of more abstract concepts. Many studies were conducted by researchers about physics, especially static fluid, to better understand them. Cooperative learning is a method in which students are assigned to small groups in the classroom, as well as other environments, where the students help each other to learn together. Students achieve more and increase their selfconfidence as individuals, develop communication skills and participate actively in this method [11]. It has been concluded from a great deal of scientific research related to the cooperative learning method, that it is more effective for student achievement [11].

The Group Investigation (GI) technique was developed by Sharan and Sharan in 1989. In this technique, the class is divided into several groups that study in a different phase of a general issue. The study issue is then divided into working sections among the members of the groups. Students pair up the information, arrangement, analysis, planning and integrate the data with the students in other groups. In this process, the teacher must be the leader of the class and ensure that students comprehend the explanations. This technique is suitable in science lessons because it encourages students to learn and attracts them to scientific research [17].

Brainstorming is method is oriented towards students' ability to express ideas, further stimulating students to be good, courageous and active thinkers in learners who have to worry about criticism or mistakes. Based on these the authors are interested in conducting research by title "The effect of Group Investigation Learning Model with Brainstroming technique on Students Learning Outcomes". 


\section{METHODE}

This research is experiment in SMA N 9 Kupang with Randomised Postest Only Control Group Design which are illustrated as in the Table below

\begin{tabular}{ccc}
\hline Sample & Treatment & Post test \\
\hline Experiment & $\mathrm{X}_{1}$ & $\mathrm{~T}_{1}$ \\
Control & $\mathrm{X}_{2}$ & $\mathrm{~T}_{2}$ \\
\hline
\end{tabular}

Table 1. Research Design

Population in this research is all student of class XI IPA SMA Negeri 9 Kupang year lesson 2015/2016. The sample consisted of students from ages 15 to17. The selected sample is 40 students of class XI IPA 1 as the experimental class and 38 students of class XI IPA 2 as the control class using Simple Random Sampling technique. All classes were given the same task and allotted time. The instrument used is 13 item description tests. Data collection and analysis techniques are carried out as follows.

\begin{tabular}{clll}
\hline Instrument & $\begin{array}{c}\text { Instrument } \\
\text { validation }\end{array}$ & $\begin{array}{c}\text { Test prerequisite } \\
\text { analysis }\end{array}$ & Hypothesis testing \\
\hline description tests & $\begin{array}{l}\text { Validity test, } \\
\text { reliability test }\end{array}$ & $\begin{array}{l}\text { normality test, } \\
\text { homogeneity test }\end{array}$ & $\begin{array}{l}\text { two tiled t-test, one } \\
\text { (right) tailed t-test }\end{array}$ \\
\hline
\end{tabular}

Table 2. Data collection and analysis techniques

Instruments that have been made in the trial then tested the validity and reliability first so as to obtain the appropriate instrument used. Before performing the hypothesis test, then first test prerequisite analysis is tested normality and homogeneity test. The first hypothesis test was performed using a two tailed t-test. The statistical equations used for the first and second hypothesis are:

$$
t=\frac{\overline{X_{1}}-\overline{X_{2}}}{S \sqrt{\frac{1}{n_{1}}+\frac{1}{n_{2}}}}
$$

with $S^{2}=\frac{\left(n_{1}-1\right) S_{1}^{2}+\left(n_{2}-1\right) S_{2}^{2}}{n_{1}+n_{2}-2}$

(Sudjana, 2002)

testing criteria: accept $\mathrm{H}_{0}$ if $-\mathrm{t}_{1-1 / 2 \alpha}<\mathrm{t}_{\text {acount }}<\mathrm{t}_{1-1 / 2 \alpha}$ when $\mathrm{t}_{\text {tabel }}$ with opportunities $(1-1 / 2 \alpha)$, dk 76 For the other $t$ value $\mathrm{H}_{0}$ is rejected.

The second hypothesis test was performed using a one tailed (right sided) t-test. Testing criteria: accept $\mathrm{H}_{0}$ if $\mathrm{t}_{\text {acount }}<\mathrm{t}_{(1-\alpha)}$ when $\mathrm{t}_{\text {tabel }}$ with opportunities $(1-\alpha)$, dk 76 For the other $\mathrm{t}$ value $\mathrm{H}_{0}$ is rejected.

\section{RESULT \& DISCUSSION}

The results obtained in this study are average value of student learning outcomes of experiment class 72.05 and control class 63.31. This data is shown as the following diagram. 


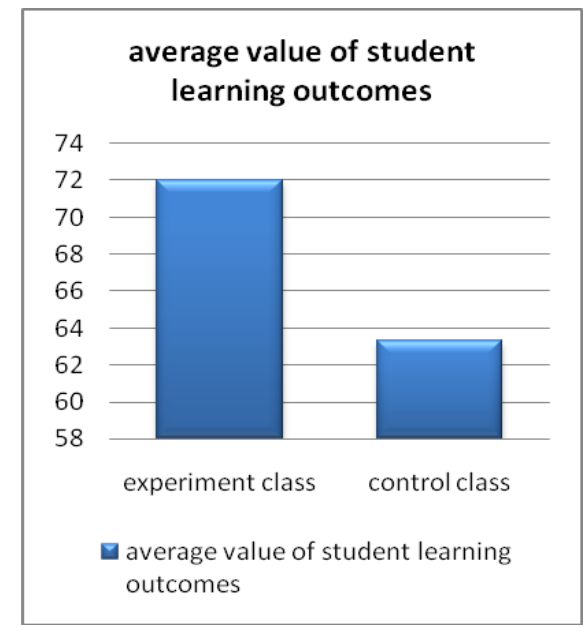

Image1.1 Average value of student learning outcomes.

Based on these data it can be seen that the students learning outcomes in the cognitive domain differ between the experimental class and the control class. It appears that the experimental class learning outcomes are higher than the control class. Statistical tests were performed using t-test. The first hypothesis test using two tailed t-test is obtained $t_{\text {count }} 7.27$ and $t_{\text {tabel }} 1.99$ with opportunities $(1-1 / 2 \alpha)$, dk 76 . Because $t_{\text {count }}>t_{\text {tabel }}$ so $\mathrm{H}_{0}$ rejected and Ha accepted which means there are differences in learning outcomes in the cognitive domain. The second hypothesis test using one tailed t-test is obtained $t_{\text {count }} 7.27$ and $t_{\text {tabel }} 1.66$ with opportunities (1- $\left.\alpha\right)$, dk 76. Because $t_{\text {count }}>t_{\text {tabel }}$ so $\mathrm{H}_{0}$ rejected and Ha accepted which means the students physics learning outcome who were taught using brainstorming techniques on the GI learning model were higher than students who were taught using the brainstorming technique on the Jigsaw Learning model.

Based on the data obtained is seen GI learning model with brainstroming technique provide better influence on student learning outcomes, especially in the cognitive domain. Use of this model makes students more active in following the lessons, because students are involved since the selection of topics to be discussed and studied further. Students feel free to contribute to the topics covered. In addition students feel more enthusiastic because they will study the topics learned in accordance with the interest so that students do not feel burdened. At the group division stage, students are also given responsibilities in groups. At the stage of investigation after students have been in their respective groups, students will be free in creating and imagining so that self-confidence will also increase. Students working in groups will practice to work together through the discussion phase. At the discussion stage each student is required to express his opinion, so that students will get used to speaking systematically.

In the control class, students will be divided into groups of origin and expert groups. The sub topics students learned were obtained by means of students counting 1 to 2 in the original group. Students who get number 1 will study subtopic number 1 and students who get number 2 will discuss sub topic 2. Once all the students in the original group get their own sub topics, they will join students from other groups of origin who get the same sub topic. They will form a group of experts to discuss and study the material together. Each group of experts consists of 16 students. They will form a small group of 4 students to experiment. Based on the observations during the research, there are students who are less enthusiastic in studying the material discussed. This is because the sub topic obtained less favorable. In addition, some groups convey inappropriate information. It causes misconception. Some of these causes may be factors so that the learning outcomes in the control class are lower than the experimental class. 
This study clearly supports the research that showed a relationship between Group Investigation learning model and student achievement, which identifies Group investigation learning model as a means to increase students' academic performance. Relevant research is a study that has previously been done by Garonia L. Parchment which examined the effectiveness of jigsaw and group investigation cooperative learning methods in a 9th grade living environment (LE) class. This study was carried out in four different LE classes during the 2008-2009 academic year. This comparison showed the GI method rendering a slightly higher assessment average and lower standard deviation value $(\mathrm{M}=79, \mathrm{SD}=12$, $\mathrm{N}=45)$ than the jigsaw assessments $(\mathrm{M}=78, \mathrm{SD}=24 \& \mathrm{~N}=46)$. Percentages of Assessment Scores 65 or Higher in Jigsaw, Group Investigation, and Traditional Instruction Methods are shown on the following table:

\begin{tabular}{cc}
\hline Instruction & Mean \\
\hline Jigsaw & 79 \\
GI & 90 \\
Traditional & 68 \\
\hline
\end{tabular}

Table 3. Percentages of Assessment Scores 65 or Higher in Jigsaw, Group Investigation, and Traditional Instruction Methods (G. L. Parchment, 2009)

Based on the data of table, GI seemed to be the most effective on student academic performance.

Based on the results of research conducted by David W. Johnson, Roger T. Johnson, and Mary Beth Stanne [2] it was found that GI learning model is superior to jigsaw learning model. The cooperative learning methods may be ranked by the size of the effect they have on achievement and by the number of comparisons available. When the impact of cooperative lessons is compared with competitive learning, when the impact of cooperative lessons is compared with individualistic learning. It is seen that the investigative group learning model is more awaited than the jigsaw learning model. In aditional, methods of cooperative learning were evaluated on five dimensions: (a) ease of learning the method, (b) ease of initial use in the classroom, (c) ease of long-term maintenance of use of the method, (d) robustness of the method (applicability to a wide variety of subject areas and grade levels), and (e) ease of method's adapting to changing conditions. Based on the evaluation, obtained the total score of group investigation learning model higher than jigsaw learning model.

Some of the results are in line with the results of this study. The updated result of this research is using brainstroming method in each model.

\section{CONCLUSION}

Based on the results of research and data analysis, it can be concluded that there are differences in student physics learning outcomes in the cognitive domain between students taught by using Group Investigation (GI) learning model with brainstorming technique and students taught using Jigsaw learning model with brainstorming technique. The result of student physics learning outcomes that was taught by using Group Investigation (GI) learning model with brainstorming technique was higher than students taught using Jigsaw learning model with brainstorming technique.

The results of this study can be used as a reference for teachers to apply the Group Investigation (GI) learning model with brainstorming technique in the learning process in the classroom so that it can help overcome the problems faced, especially in the learning outcomes in the cognitive domain. For other researchers need to do research on other factors that can give a direct impact or influence on student physics learning outcomes such as learning methods, how to learn students, the quality of interpretation and student 
responses so that the learning process that occurs in the classroom more effective and efficient.

The preparation of this research and article supported by headmaster and science teachers of SMA N 9 Kupang, all those who have contributed comments and insights.

\section{REFERENCES}

1. A. Pitoyo, H. J. Waluyo, S. Suwandi, Adnyani, JEP, 5(1), 21-29 (2014)

2. D. W. Johnson, R. T. Johnson, M. B. Stanne, Cooperative Learning Methods: A Meta Analysis, (University of Minnesota, 2000)

3. E. A. Al-ziadat, M. H. Alsaaideh, D. R. Al-Elaimat, IJE, 5(3), 184-199 (2013)

4. F. Ahsanah, TELL J., 3(1), 57-69 (2015)

5. G. L. Parchment, A Study Comparing Cooperative Learning Methods: Jigsaw \& Group Investigation (2009)

6. H. C. Chen. AJKN, 69-82 (1999)

7. H. Nanang, S. Cucu, Konsep Strategi Pembelajaran, (Bandung: Refika Aditama, 2010)

8. I M. Astra, C. Wahyuni, H. Nasbey, JEP, 6(11), 75-79 (2015)

9. J. F. D. Sitinjak, Sahyar, J. Inpafi, 3(2), 60-66 (2015)

10. J. S. Mari, S. A. Gumel, IJIET, 5(3), 196-199 (2015)

11. N. Okur akçay, K. doymuş, EBAD-JESR, 2, 109-123 (2012)

12. K. Smith, Startegies for Effective Teaching a Handbook for Teaching Assistants. University of Minnesota : E-book (2009)

13. M. N. Adora, IJHMS, 2, 146-147 (2014)

14. S. Jongsermtrakoon and J. Nasongkhla, IJIAET, 5(10), 783-788 (2015)

15. S. Ying Chu, IJMSR, 2. 166-172 (2014)

16. Setiawan, Hakim, Indeks Pembangunan Manusia, (Universitas Islam Indonesia, 2013)

17. S. J. Sherman, Cooperative learning and science (Westport, CT: Greenwood Press. pp. 226-244, 1994)

18. S. Mehta, A. K. Kulshrestha, Implementation of Cooperative Learning in science: ADevelopmental-cum-Experimental Study, (Hindawi Publishing corporation, 2014)

19. Sudjana, Metode Statistika, (Bandung: Tarsito, 2002)

20. V. D. Tran, IJHE, 3(2), 131-140 (2014) 